\title{
35. CHLOROPHYLL DERIVATIVES IN DSDP LEG 22 SEDIMENTS $^{1}$
}

\author{
G. Dale Smith and Earl W. Baker, Department of Chemistry, Northeast Louisiana University, Monroe, Louisiana
}

\section{INTRODUCTION}

The investigation of deep ocean sediment core samples yields information on the intermediate products and mechanisms of the diagenetic transformation of chlorophyll to the more thermally stable petroporphyrins. The understanding of the chemical fossilization of these and other organic debris has, in the last few years, been greatly increased by the results of selected Deep Sea Drilling Project sediment core sample investigations.

Chlorins associated with Recent sediments (Baker, 1970; Baker and Smith, in press) and porphyrins occurring in Ancient sediments and bitumens (Hodgson et al., 1967; Baker et al., 1967) have been isolated and characterized. The results of the various analyses suggest that the tetrapyrrole system, the basic ring structure of chlorophylls, may serve as a "biological marker" due to its thermal stability in geochemical environments (Baker, 1969). Thus, the presence and state of the tetrapyrrole system function as a measure of diagenetic activity and geochemical conditions of past to present.

The investigation of a spectrum of Pleistocene to Upper Cretaceous core samples from Leg 22, Sites 217 and 218 should aid in elucidating the mechanisms and reaction sequence of the diagenetic conversion of chlorophyll to petroporphyrins.

\section{DISCUSSION}

The pertinent geological data and absorption spectra of the tetrapyrrole pigments extracted from sediments taken at Sites 217 and 218 are given in Table 1. Total pigment was separated into red and green components by chromatography and in line with conventional terminology, the green pigments have been called chlorins and the red ones, porphyrins.

The yield of pigment was very low from Site 217 cores, undetectable spectrophotometrically in three cores, and less than $10 \mathrm{ppm}$ in the other two Site 217 samples investigated. The yield of tetrapyrrole was higher from Site 218 , varying inversely porportional to core depth (Figure 1a).

Samples of the green pigment from Sites 217 and 218 were found as free base chlorins. The absence of metallochlorin as in previous deep-sea sediment studies (Baker, 1970; and Baker and Smith, in press) suggests that loss of magnesium from chlorophyll is a facile process, occurring at or before the pigment reaches the sedimentwater interface.

\footnotetext{
${ }^{1}$ Research supported by Oceanographic Section, National Science Foundation, NSF Grant GA 37962.
}

The chlorins isolated from Sample 218-05-02, an upper Pleistocene sample, gave electronic spectra very similar to chlorins of Pleistocene age from Site 147 (Leg 15) with identical placement of the major absorption bands (Baker and Smith, in press). Combined electronic and mass spectral data indicate that pheophorbide (molecular weight 872 , 858 , and 830 ) and chlorin $\mathrm{P}_{6}$ (molecular weight 890 and 624) type tetrapyrroles are present in the Recent sediments.

The pheophorbide-like electronic spectra are consistent only with intact chromophores, suggesting a dihydrophytol pheophorbide structure for the pigments of molecular weight 872 and 858 . Pheophytin $a$ and $b$ are likely precursors.

The isolation of dihydrophytol pheophorbide from Recent and Pleistocene cores is accompanied by the detection of substantial amounts of phytadiene (Simoneit, in preparation); see figure $1 \mathrm{~b}$. Apparently the pheophytins undergo diagenetic degradation in the early reducing environments by dual pathways: (1) reduction of the phytyl double bond leading to dihydrophytol pheophorbide or (2) loss of the phytyl group by an "internal elimination" to give phytadiene. This would explain the apparent absence (or at least sub-detectable quantities) of pheophytin $a$ in deep-sea sediments.

Following reduction of the phytyl side chain double bond, which inhibits the internal elimination, deesterification by "normal hydrolytic" mechanisms appears to be a slow process. These analyses indicate that, at least in deep ocean sediments, ester linkages formed in the Pleistocene and Pliocene eras are preserved.

The group of green pigments yielding chlorin $\mathrm{P}_{6}$ type spectra (molecular weight 890 and 624) is proposed to arise by isocyclic ring opening of the dihydrophytol pheophorbide and pheophorbide from the reduction and elimination reactions of pheophytin. The observation of these compounds in Recent cores suggests that etioporphyrin series formation begins in early chlorophyll diagenesis in deep-sea sediments.

The position of the electronic absorption red band of Site 218 chlorins shifts from $663 \mathrm{~nm}$ in the Pleistocene sample to $660 \mathrm{~nm}$ in upper Miocene to $656 \mathrm{~nm}$ in lower Miocene. This suggests more complete reduction of ring conjugating groups, such as the 9-keto or 2-vinyl, occurs with increased core depth and age.

Site 218 Miocene cores yielded both green and red pigments. The major peaks at 395,525 , and $555 \mathrm{~nm}$ in the electronic spectra of the red fractions indicate the porphyrins are chelated with metal. Vanadyl petroporphyrins isolated from Athabasca tar sands gave a Soret band at $404 \mathrm{~nm}$; nickel petroporphyrins from gilsonite gave a Soret at $387 \mathrm{~nm}$. Baker (1966) and Baker et al. (1967) have 
TABLE 1

Core Description

\begin{tabular}{|c|c|c|c|c|c|c|c|c|}
\hline \multirow{3}{*}{$\frac{\text { Sample }}{217-2-4}$} & \multirow{3}{*}{\begin{tabular}{|c}
$\begin{array}{c}\text { Geologic } \\
\text { Age }^{\mathrm{a}}\end{array}$ \\
Pliocene
\end{tabular}} & \multirow{3}{*}{$\begin{array}{c}\begin{array}{c}\text { Organic } \\
\text { Carbona } \\
(\%)\end{array} \\
0.2\end{array}$} & \multirow{3}{*}{$\begin{array}{c}\begin{array}{c}\text { Pigment } \\
\text { Yield } \\
\text { (ppm) }\end{array} \\
\quad \simeq 10\end{array}$} & \multicolumn{5}{|c|}{ Tetrapyrrole Pigments } \\
\hline & & & & \multicolumn{4}{|c|}{$\begin{array}{l}\text { Electronic Spectrum } \\
(\mathrm{nm})\end{array}$} & \multirow{2}{*}{$\begin{array}{r}\text { Type } \\
\text { Chlorin }\end{array}$} \\
\hline & & & & 410 & & & 663 & \\
\hline $217-10-4$ & Eocene & 0.1 & & & & & & \\
\hline $217-18-2$ & $\begin{array}{l}\text { Upper } \\
\text { Cretaceous }\end{array}$ & 0.1 & & & & & & \\
\hline $217-27-2$ & $\begin{array}{l}\text { Upper } \\
\text { Cretaceous }\end{array}$ & 0.1 & & & & & & \\
\hline $217-32-2$ & $\begin{array}{l}\text { Upper } \\
\text { Cretaceous }\end{array}$ & 0.1 & $\simeq 10$ & 392 & & $(550)$ & & Nickel porphyrin \\
\hline $218-5-2$ & Pleistocene & 0.4 & 80 & 408 & & 663 & 680 & Chlorin \\
\hline 218-11-2 & Pliocene & 0.4 & & & & & & \\
\hline $218-19-1$ & Miocene & 0.5 & 84 & $\begin{array}{l}408 \\
394\end{array}$ & 525 & 555 & 660 & $\begin{array}{l}\text { Chlorin } \\
\text { Nickel porphyrin }\end{array}$ \\
\hline $218-22-2$ & Miocene & 0.3 & 72 & $\begin{array}{l}408 \\
395\end{array}$ & 525 & 555 & 660 & $\begin{array}{l}\text { Chlorin } \\
\text { Nickel porphyrin }\end{array}$ \\
\hline $218-25-2$ & Miocene & 0.3 & 48 & $\begin{array}{l}405 \\
396\end{array}$ & 520 & 558 & 656 & $\begin{array}{l}\text { Chlorin } \\
\text { Nickel porphyrin }\end{array}$ \\
\hline
\end{tabular}

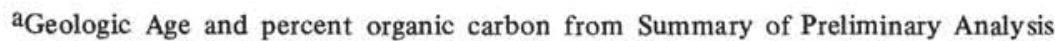
of Site 217 and 218 cores.

shown that these pigments consists of only chelated homologous series of alkyl- and cycloalkylporphyrins.

The observed data from Site 218 samples indicate that the chelating metal is nickel. The displacement of the Soret band from $387 \mathrm{~nm}$ for nickel alkylpetroporphyrins from gilsonite to $395 \mathrm{~nm}$ for Site 218 Miocene samples is probably due to conjugation of ring substituents, such as carboxylic acids. In the Upper Cretaceous Site 217 pigment electronic spectrum, the Soret is located at $392 \mathrm{~nm}$, a blue shift toward nickel alkyl petroporphyrin.

The nickel porphyrins and free base chlorins were detected in three Miocene samples spanning a 211-meter depth range. The absence of metallochlorin and the simultaneous occurrence of free base chlorin and metalloporphyrin suggest that metallation and aromatization are concerted reactions in deep ocean sediment chlorophyll diagenesis.

\section{EXPERIMENTAL}

\section{Treatment of Cores}

A flow sheet outlining the experimental procedures used in treating the Leg 22 core samples is given in Figure 2.

The frozen cores were broken up into approximately 120-gram samples and exhaustively extracted with $90 \%$ acetone-10\% methanol using a 1.0 -liter ball mill. The combined extracts were reduced to dryness, taken up in freshly distilled tetrahydrofuran and chromatographed on Sephadex LH-20 (for column preparation, see Baker, 1970). The various pigment-containing fractions were then treated with diazomethane to convert any free acid functions to esters. Rechromatography over sugar (80-100 mesh) with cyclohexane-benzene fractionated the pigments into the respective chlorin and porphyrin tetrapyrroles.
During Leg 15 core analyses, extreme difficulty was encountered in separating the free base tetrapyrrole (chlorin in the case of Leg 15) from a "hydrocarbon impurity" which tended to block out the visible spectra at high energy. However, the laboratory-prepared metallochlorin derivatives could be chromatigraphed to yield a pigment fraction of suitable purity for spectrometry (Baker and Smith, in press).

Following this procedure, the chlorin pigments were treated with zinc acetate in acetone and chromatographed over neutral alumina with benzene and benzene with $0.5 \%$ and $2.0 \%$ methanol to give pigment fractions of considerably increased purity. After demetalation with hydrochloric acid, the pigments were subjected to electronic and mass spectral analysis.

Chlorins were not detected in the lower Miocene and Cretaceous samples. The porphyrin tetrapyrroles extracted from these cores were isolated by repetitive chromatography over sugar and neutral alumina. Where insufficient sample for mass spectrometric analysis was isolated, the pigment was treated with methane-sulfonic acid and analyzed by fluorescence spectrometry.

\section{Mass Spectrometry}

The mass spectra were obtained on an AEI MS-9 spectrometer fitted with a direct probe sample injection system. The pigment was transferred to the probe with a drop of benzene. After removal of solvent with the rough pump, the sample was quickly injected and the spectrum recorded. Spectra were obtained at $70 \mathrm{ev}$ and $12 \mathrm{ev}$ at about $320^{\circ}$ to $330^{\circ}$. 

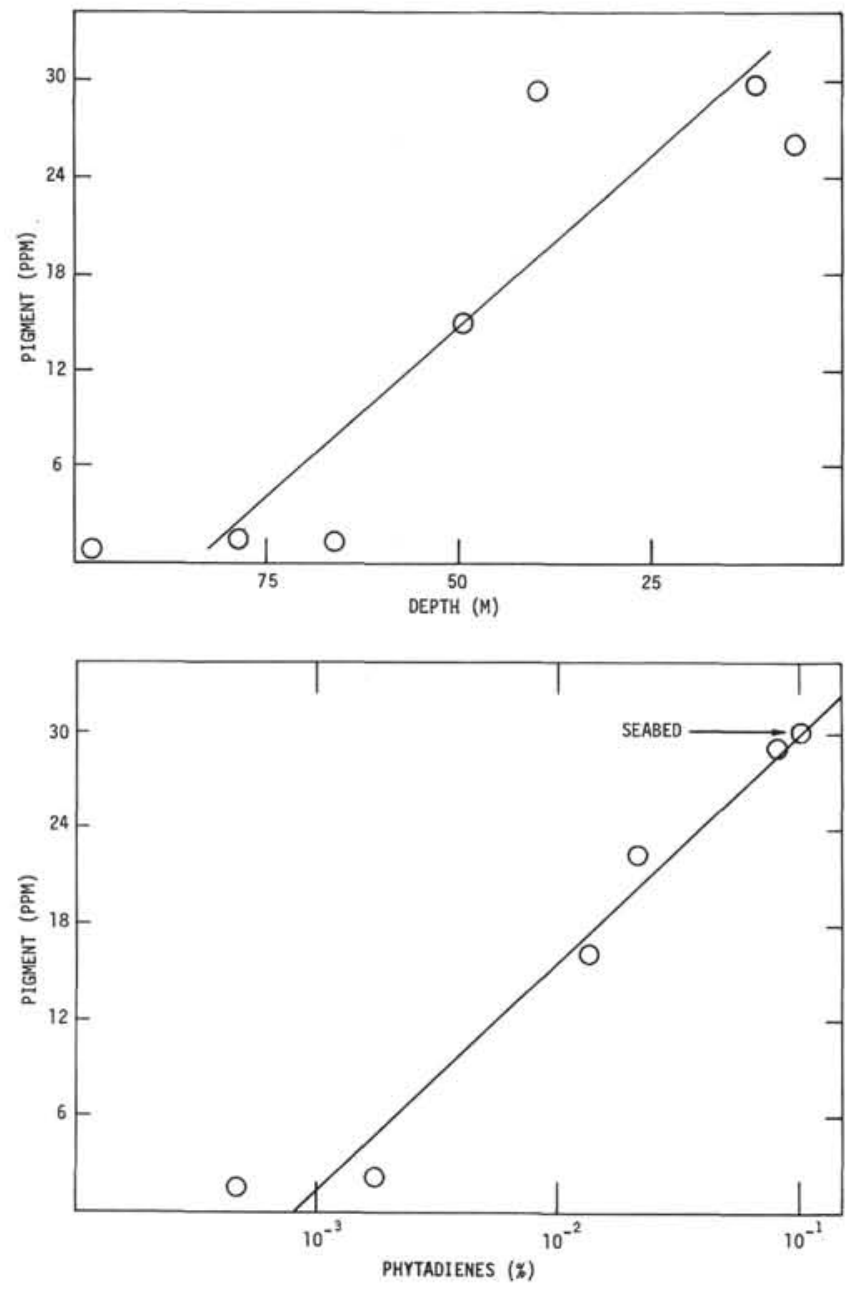

Figure 1. (a) Total tetrapyrrole pigment yield versus core depth; (b) total tetrapyrrole pigment yield versus phytadiene yield.

\section{ACKNOWLEDGMENT}

This research was supported by the Oceanography Section of the National Science Foundation, NSF Grant GA-37962. Appreciation is hereby expressed to the scientists, engineers, and administrators of the Joint

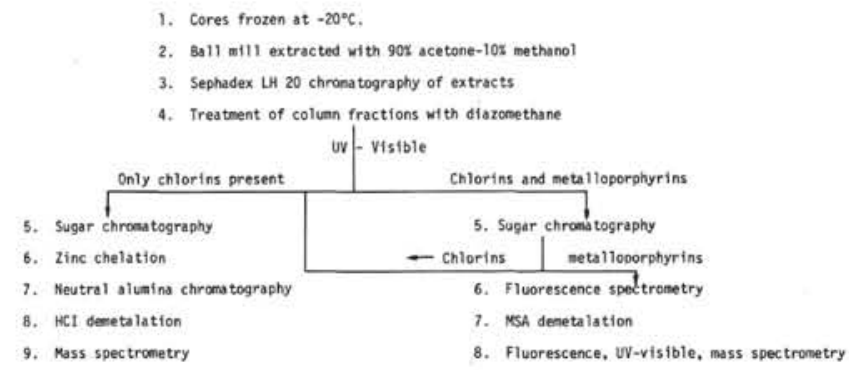

Figure 2. Experimental procedure flow sheet.

Oceanographic Insitutions for Deep Earth Sampling (JOIDES), Scripps Institution for Oceanography, and the National Science Foundation. Grateful acknowledgment is extended to Dr. Jim Boal of the Mellon Institute for obtaining the mass spectra.

\section{REFERENCES}

Baker, E. W., 1966. Mass spectrometric characterization of petroporphyrins: J. Am. Chem. Soc., v. 88, p. 2311.

1969. Organic geochemistry, Eglinton, G. and Murphy, M. T. J. (Eds.), New York (Springer-Verlag), p. 479.

, 1970. Tetrapyrrole pigments. In Initial Reports of the Deep Sea Drilling Project, Volume IV: Washington (U. S. Government Printing Office), p. 431.

Baker, E. W. and Smith, G. D., in press. Chlorophyll derivatives in Sediments. In Initial Reports of the Deep Sea Drilling Project, Volume XV: Washington (U.S. Government Printing Office).

Baker, E. W., Yen, T. F., Dickie, J. P., Rhodes, R. E., and Clark, L. F., 1967. Mass spectrometry of porphyrins II. characterization of petroporphyrins: J. Am. Chem. Soc., v. 89, p. 3631 .

Hodgson, G. W., Baker, B. L., and Peake, E., 1967. Fundamental aspects of petroleum geochemistry: Nagy, B. and Colombo, V. (Eds.), New York (Elsevier), p. 242.

Simoneit, B. R., in preparation. Phytadienes in Recent anoxi deep sea sediments: Geochim Cosmochim. Acta. 